\title{
Production of intravenous human dengue immunoglobulin from Brazilian-blood donors
}

\author{
Frederico Leite Gouveia ${ }^{1, *}$, Renata Mendes Batista de Oliveira ${ }^{1}$, Antônio Edson de Souza Lucena ${ }^{2}$, \\ Marli Tenório Cordeiro ${ }^{3}$, Ana Cristina Lima Leite ${ }^{1}$
}

\author{
${ }^{1}$ Department of Pharmaceutical Sciences, Federal University of Pernambuco, ${ }^{2}$ Empresa Brasileira de \\ Hemoderivados e Biotecnologia, ${ }^{3}$ Department of Virology and Experimental Therapy, \\ Research Center Aggeu Magalhães, Oswaldo Cruz Foundation
}

\begin{abstract}
Dengue represents an important health problem in Brazil and therefore there is a great need to develop a vaccine or treatment. The neutralization of the dengue virus by a specific antibody can potentially be applied to therapy. The present paper describes, for the first time, the preparation of Immunoglobulin specific for the dengue virus (anti-DENV IgG), collected from screened Brazilian blood-donations. Production was performed using the classic Cohn-Oncley process with minor modifications. The antiDENV IgG was biochemically and biophysically characterized and fulfilled the requirements defined by the European Pharmacopoeia. The finished product was able to neutralize different virus serotypes (DENV-1, DENV-2, and DENV-3), while a commercial IgG collected from American blood donations was found to have low anti-dengue antibody titers. Overall, this anti-DENV IgG represents an important step in the study of the therapeutic potential and safety of a specific antibody that neutralizes the dengue virus in humans.
\end{abstract}

Uniterms:. Viral infections. Dengue/treatment. Dengue/virus/neutralization. Immunoglobulins/ preparation. Plasma fractionation. Virus neutralization.

\begin{abstract}
A dengue representa um importante problema de saúde no Brasil, portanto, a identificação de vacina ou tratamento eficaz é uma necessidade urgente. A neutralização do vírus da dengue, por anticorpo específico, tem potencial aplicação terapêutica. Descrevemos aqui, pela primeira vez, a preparação de imunoglobulina específica para o vírus da dengue (IgG anti-DENV), produzida a partir do plasma selecionado de doadores brasileiros. A produção foi realizada utilizando o método clássico de Cohn-Oncley com pequenas modificações. A IgG anti-DENV foi bioquimicamente e biofisicamente caracterizada e cumpriu os requisitos definidos pela Farmacopeia Europeia. O produto final foi capaz de neutralizar diferentes sorotipos do vírus (DENV-1, DENV-2 e DENV-3), enquanto que a IgG comercial, produzida a partir do plasma de doadores americanos, apresentou baixos títulos de anticorpos anti-dengue. No geral, esta IgG anti-DENV representa uma importante etapa para o estudo do potencial terapêutico e segurança da neutralização, por anticorpos específicos, do vírus da dengue em humanos.
\end{abstract}

Unitermos: Infecções virais. Dengue/tratamento. Dengue/vírus/neutralização. Imunoglobulinas específicas/preparação. Fracionamento de plasma. Neutralização viral.

\section{INTRODUCTION}

There are around 2.5 billion people living in areas endemic for dengue fever and it is estimated that there are 100 million infections annually (Gubler 1998). The

\footnotetext{
"Correspondence: F. L. Gouveia. Departamento de Ciências Farmacêuticas, Universidade Federal de Pernambuco. Av. Prof Moraes Rego, 1235, 50670-901

- Recife - PE, Brasil. E-mail: fredgouveia@outlook.com
}

burden of dengue in endemic countries weighs heaviest on children. However, there has been an increasing trend towards adult infection in certain countries (Ooi, Goh, Gubler, 2006; Cummings et al., 2009). Most travelers with dengue have been adults (Wilder-Smith, Schwartz, 2005). Currently, neither cure nor vaccines are available, and new therapies are thus urgently needed. Although there have been considerable developments in medicinal chemistry, no promising small-organic compounds endowed with 
virus inhibition activity have emerged (Yin et al., 2009). Passive transfer of specific antibodies is thus the most promising way of treating viral infections in such a way as to promote speedier patient recovery.

The dengue virus belongs to the Flaviviridae family and there are four known serotypes: DENV-1, DENV-2, DENV-3, and DENV-4. All four virus serotypes cause a spectrum of illness ranging from asymptomatic or mild febrile disease to classical dengue fever (DF) and to more severe disease manifesting as dengue hemorrhagic fever (DHF) and dengue shock syndrome (DSS) (Souza et al., 2009). The severity of the disease is likely to depend on various factors, including the strain and serotype of the infecting virus, the age and genetic background of the patient and the degree of viremia (Guzman, Kouri, 2002; Vaughn et al., 2000). Many prospective, population-based cohort and clinical studies have established secondary infections with a heterotypic dengue virus serotype as a major risk factor for severe disease. Antibodydependent enhancement (ADE) involves the boosting of virus replication in $\mathrm{Fc}$-receptor bearing cells (especially monocytes and macrophages) by way of pre-existing, non-protective levels of cross-reactive dengue antibodies. It is postulated that ADE results in an amplified cascade of cytokines and complement activation causing endothelial dysfunction, platelet destruction, and consumption of coagulation factors, which result in plasma leakage and hemorrhage (Halstead, 1979, 2003).

DENVs have given rise to large outbreaks in Brazil in the past 25 years with more than 5 million reported cases. (Figueiredo, 2010). Given that approximately 50\% of DENV-infected individuals remain asymptomatic, and that the duration of viremia prior to the onset of symptoms is estimated at 1 to 2 days, it is possible that viremic individuals donate blood and serve as a source of dissemination of the virus in the community (Mohammed et al., 2008; Linnen et al., 2008; Tambyah et al., 2008; Chuang et al., 2008; Nishiura, Halstead, 2007). The first epidemic of dengue fever in Brazil, with isolation of the virus, occurred in 1981, in the State of Roraima, where DENV-1 and DENV-4 were identified (Osani et al., 1983). In 1986, DENV-1 was identified in the State of Rio de Janeiro (Nogueira et al., 1988) and subsequently spread to other States in Brazil.

Polyvalent (i.e. normal) intravenous immunoglobulins G (IVIGs) are collected from 1,000 to 10,000 healthy blood-donors. The first therapeutic use of polyvalent IgGs was for antibody replacement therapy (Orange et al., 1949). However, many other clinical benefits of IVIGs have been demonstrated. They have been used for bone marrow and organ transplantation, to treat chronic inflammatory demyelinating polyneuropathy, severe asthma, pediatric HIV, dermatomyositis, idiopathic thrombocytopenic purpura as well as multiple sclerosis (Achiron et al., 1998; Achiron et al., 2000; Brennan, 2001; Dalakas et al., 1993; Hann et al., 1996; Lories et al., 2000; Ohlsson, Lacy, 2001). Different from the polyvalent IVIGs, for the production of specific IVIG (i.e., hyper-immune), intact IgG are collected from the plasma of blood-donors previously identified as having high levels of a specific antibody or at least a population of similar antibodies. Examples are the Hepatitis B, tetanus, cytomegalovirus, or rabies anti-IgGs (Atkins et al., 2000; Gelfand, 2001). The most classic examples of specific IVIG are the anti-D IgG (Rho) and anti-hepatitis B IgG (Okwundu, Afolabi, 2013).

Given this, it is still not known what implications might arise from a treatment based on IVIG prepared from Brazilian blood-donors (anti-dengue antibodies) for neutralizing the virus. Another question is that of whether specific anti-dengue IVIG preparation is efficient and safer for dengue treatment. To date, no anti-dengue IVIGs collected from a pool of blood-donors have been produced. To address this, the present study describes the plasma screening, fractionation and biochemical validation of anti-dengue IgG prepared from a plasma pool of Brazilian blood donors. Among the procedures available for producing specific anti-IgGs in a laboratorial scale, we choose the classic Cohn-Oncley protocol (Lucena et al., 2010). The production process here also includes two dedicated virus clearance steps, being thus a combination of the currently used Cohn-Oncley protocol with modifications.

\section{MATERIAL AND METHODS}

\section{Plasma selection}

A plasma pool from blood-donations received at the Pernambuco Hematology and Hemotherapy Foundation - HEMOPE (in the State of Pernambuco, in the Northeast Region of Brazil) was collected and the plasma bags considered free of contamination were selected. Once the contamination-free plasma bags were selected, the plasma rich in anti-dengue IgG was separated. To this end, a commercial ELISA kit (E-DEN01G panbio diagnostics, Cheshire, UK) was used for the indirect measurement of anti-dengue antibodies. This ELISA kit adsorbs dengue antigens on the plate and ELISA reveals them using horse peroxidase in combination with anti-human IgG. This ELISA kit was also used on plasma without the antidengue IgG (the negative control). 


\section{Immunoglobulin fractionation}

The IgG was precipitated out from the crude plasma using the Cohn-Oncley process (cold ethanol precipitation) with minor modifications. The general process is depicted in Figure 1. The process of cold ethanol precipitation is based on tuning the protein solubility by adjusting $\mathrm{pH}$, temperature, salt concentration, and ethanol (Cohn et al., 1946). In short, the frozen plasma is thawed until it reaches $4{ }^{\circ} \mathrm{C}$, at which temperature fibrinogen and clotting factor VIII are insoluble and are precipitated out. The cryo-precipitate is then removed by centrifugation and the cryo-free plasma is treated using Method 6 from Cohn et al. (1946). Fibrinogen was precipitated in fraction I and immunoglobulin was separated off from albumin by II + III precipitation. The precipitates were separated from the supernatants by centrifugation.

In accordance with Oncley et al. Method 9 (1949), fraction II + III was suspended and fraction III was separated off. The supernatant was clarified by depth filtration with the aid of a filter. From this filtrate, an IgG paste was obtained and collected by centrifugation. The IgG paste was then dissolved in sterile water for injection and clarified by depth filtration with the aid of a filter.

To reduce the ionic forces, the solution was filtered through ultrafiltration membranes (diafiltration) with sterile water for injection, followed by protein concentration adjustment to $5 \%(\mathrm{w} / \mathrm{v})$. A $30 \mathrm{kD}$ Millipore Pellicon Systen was used to perform diafiltration and protein level adjustment. Virus inactivation was performed using a solvent (tri- $n$-butyl phosphate; TNBP) and a detergent (Tween 80) (Horowitz et al., 1985). To remove the solvent and detergent, a cation-exchange chromatography using a CM Sepharose FF stationary phase was performed. Yet to remove immunoglobulin A and other components, an anion-exchange chromatography in DEAE Sepharose FF was carried out. The flow-through was concentrated by ultrafiltration (10 KD Millipore Pellicon System) and diafiltered with $0.25 \mathrm{~mol} / \mathrm{L}$ glycine using the same system. The protein level was adjusted to $5 \%(\mathrm{w} / \mathrm{v})$ and $\mathrm{pH}$ to 4.2-4.3. Sterilizing filtration was performed and the final solution packaged aseptically. To inactivate virus particles, the final product was incubated at $23-27^{\circ} \mathrm{C}$ for 21 days before stock at $2-8{ }^{\circ} \mathrm{C}$.

\section{Product validation}

To check the functional properties of the product during the process and of the final preparation, we performed the protocols established by the European Pharmacopoeia and described in product marketing

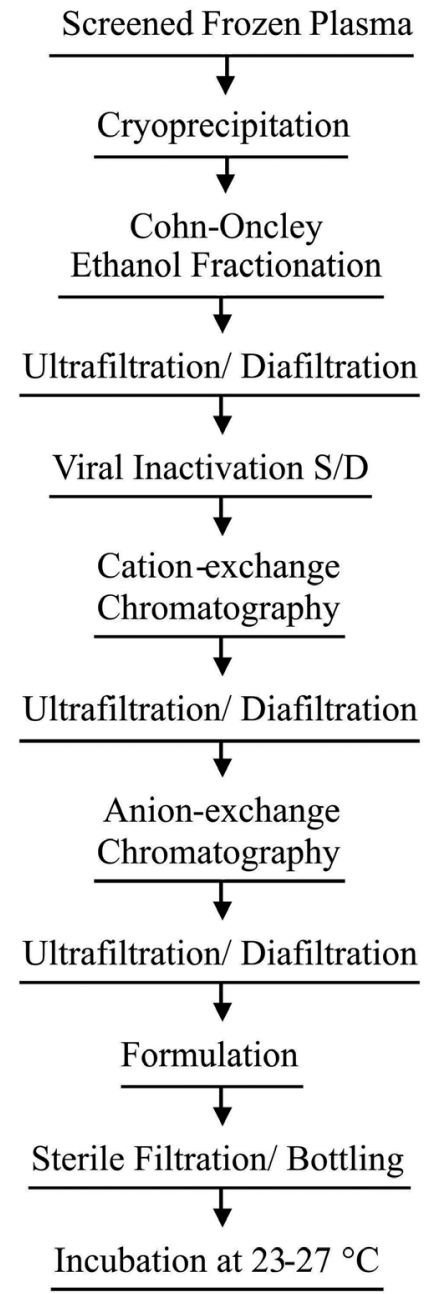

FIGURE 1 - Purification process for anti-dengue specific IgGs (Oncley et al., 1949; Lucena et al., 2010).

authorization dossiers approved by National Regulatory Authorities. Distribution of molecular size was analyzed using size exclusion chromatography with a Biosep SEC-S3000 (600 x $7.8 \mathrm{~mm})$ column (Phenomenex). Radial immune diffusion was used to determined IgM and subclass distribution of IgG. Enzyme-Linked Immunosorbent Assay (ELISA) was used to measure IgA and $\mathrm{IgE}$ and check the absence of antibodies screened for blood donation, such as Human Immunodeficiency Virus $\left(\mathrm{HIV}_{1}, \mathrm{HIV}_{2}\right)$, hepatitis B surface antigens (HBsAg), Hepatitis C (HCV), Human T lymphotropic virus (HTLV), Chagas disease and syphilis.

Cellulose acetate electrophoresis was used to measure $\gamma$-globulin. The methods used for the determination of pyrogen and anticomplementary activity were in accordance with European Pharmacopoeia monographs 2.6.8 and 2.6.17, respectively. A thermostability assay was performed by incubation of the preparation at $57^{\circ} \mathrm{C}$ for 4 hours. 


\section{Identification of anti-dengue serotypes}

To ascertain the broad neutralizing properties of the anti-dengue $\mathrm{IgG}$ described here, the neutralizing action of $\mathrm{IgG}$ was measured for different isolated serotypes. Isolated serotypes DENV-1 (PE/97-42735), DENV-2 (PE/95-3808), and DENV-3 (PE/02-95016) were supplied by the Central Laboratory of Pernambuco (LACEN-PE, Brazil). In this experiment, a commercial polyvalent IVIG (Kiovig/ Baxter International Inc, Deerfield, IL, USA) was also used. Anti-dengue antibodies for different dengue serotypes were measured using the Plaque-Reduction Neutralization Test (PRNT) (Morens et al., 1985).

First, a two-fold serial dilution of IgG (1/20 to $1 / 2.560$ ) in Minimum Essential Medium (MEM) (Invitrogen) was placed in 96-well microtiter plates to a final volume of $100 \mu \mathrm{L}$. Then, $100 \mu \mathrm{L}$ of a viral suspension (30 plaque forming units/mL) of DENV-1 (PE/97-42735), DENV-2 (PE/95-3808), and DENV-3 (PE/02-95016) was aliquoted into the respective wells. The plate was incubated for 1 hour at $37^{\circ} \mathrm{C}$ in $5 \% \mathrm{CO}_{2}$. Then, $50 \mu \mathrm{L}$ of the $\mathrm{IgG} /$ virus mixture was collected from each dilution and transferred into a 24 well-plate containing Vero cells previously seeded at a density of $3 \times 10^{6}$ cells $/ \mathrm{mL}$, in MEM supplemented with 10\% Fetal Calf Serum (FCS, GIBCO). After virus attachment (incubation for 1 hour at $37{ }^{\circ} \mathrm{C}$ in $5 \% \mathrm{CO}_{2}$ ), each well was covered with $500 \mu \mathrm{L}$ of MEM 10X medium, supplemented with $10 \%$ FBS, $1 \%$ penicillin/ streptomycin and 3\% carboxymethylcellulose. The plate was then incubated for 7 days at $37^{\circ} \mathrm{C}$ in $5 \% \mathrm{CO}_{2}$. To inactivate the virus particles, the medium was removed and the monolayer cells covered with formalin (solution at 3.5 M, $2 \mathrm{~mL}$ per well) and incubated for $1 \mathrm{~h}$. The formalin solution was washed out and the cells were stained with crystal violet ( $1: 50 \mathrm{v} / \mathrm{v}, 0.5 \mathrm{~mL}$ per well). The number of regions of infected cells (plaques) was counted and compared to the virus particles receiving only polyvalent IVIG and the non-treated virus particles.

\section{Ethics statement}

The study protocol was approved by the HEMOPE ethics committee (process number 002/2011). Patients were not identified and study data was analyzed anonymously.

\section{RESULTS AND DISCUSSION}

In Table I, we summarize the biochemical and biophysical properties of the anti-dengue IgG. The parameters showed in Table I are defined by European Pharmacopoeia and described in product marketing authorization dossiers approved by National Regulatory Authorities.

Electrophoresis showed a satisfactory level of purity with $98 \%$ of proteins migrating to the gamma region. IgG subclass content in this preparation was found to be similar to naturally occurring ratios (Morell et al., 1972).

The specific IVIG produced contained traces of IgA and IgM, immunoglobulins being mainly removed by cation-exchanged and anion-exchanged chromatographs respectively. Some authors have pointed out that the administration of IVIG preparations with significant amounts of IgA can cause severe anaphylactic reactions in patients with IgA deficiency (Vyas et al., 1968; Bjorkander et al., 1987).

The total number of aggregates present in the preparation lies within the acceptable range. IgG dimerization and aggregate formation was also associated with an increase in the risk of adverse effects (Kroez et al., 2003). These aggregates bind and activate components of the complementary system and routine determination of anticomplementary activity was therefore adopted. In the IVIG produced, consumption of the complement was not greater than $50 \%$, as required by the European Pharmacopoeia. The product was kept at $\mathrm{pH} 4.0-4.5$, which is optimal for maintaining $\mathrm{IgG}$ in an unaggregated state (Gelfand, 2006). Initially developed to produce a stable IgG solution, a low $\mathrm{pH}$ formulation was also used to achieve a final step involving inactivation of the virus.

Two steps were taken to inactivate the virus: solvent/ detergent (S/D) treatment and incubation at low $\mathrm{pH}$. $\mathrm{S} / \mathrm{D}$ treatment is very effective against lipid-enveloped viruses (Uemura et al., 1994; Chang et al., 2000). Low $\mathrm{pH}$ incubation also provides robust inactivation of lipidenveloped viruses, including HIV (Bos et al., 1998; Omar et al., 1996; Biesert, 1996; Reid et al., 1988). This product responds negatively (i.e. is non-reactive) to $\mathrm{HBsAg}, \mathrm{HCV}, \mathrm{HIV}_{1}$ and $\mathrm{HIV}_{2}$ antibodies, Chagas disease and syphilis. These are important biochemical characterizations, ensuring that the $\mathrm{IgG}$ is suitable for intravenous administration in subjects.

Completing biochemical and biophysical analysis, we examined the overall stability of this IgG preparation by way of thermo-stability. We did not observe alterations, such as gelification or flocculation. Therefore, the IVIG formulated in $0.25 \mathrm{~mol} / \mathrm{L}$ glycine demonstrated appropriate osmolality.

Once the anti-dengue IgG was carefully characterized in terms of biophysical and biochemical properties, we decided to quantify the ratio of IgG serotypes for DENV-1, DENV-2, and DENV-3. DENV-4 was not tested. Table II presents these data. This product was found to have high 
TABLE I - Anti-dengue IgG characterization

\begin{tabular}{|c|c|c|}
\hline Test & Reference values & Results \\
\hline$\overline{\mathrm{pH}} \mathrm{H}^{(\mathrm{a})}$ & $4.0-7.4$ & 4.3 \\
\hline Total protein ${ }^{(b)}$ & $45-55 \mathrm{mg} / \mathrm{mL}$ & $51 \mathrm{mg} / \mathrm{mL}$ \\
\hline Protein composition $^{(\mathrm{c})}$ & Minimum of $95 \%$ gammaglobulin & $98 \%$ \\
\hline Distribution of molecule size ${ }^{(c)}$ & $\begin{array}{l}\text { Minimum of } 90 \% \text { monomer and dimer } \\
\text { Maximum of } 3 \% \text { polymers and aggregates }\end{array}$ & $\begin{array}{l}98.1 \% \\
1.1 \%\end{array}$ \\
\hline $\operatorname{IgA}$ & - & $0.16 \mathrm{mg} / \mathrm{mL}$ \\
\hline $\operatorname{IgM}$ & - & $0.10 \mathrm{mg} / \mathrm{mL}$ \\
\hline Subclass distribution & Percent & Percent \\
\hline $\operatorname{IgG}_{1}$ & $65-70$ & 68 \\
\hline $\mathrm{IgG}_{2}$ & $20-25$ & 19 \\
\hline $\mathrm{IgG}_{3}$ & $7-10$ & 7 \\
\hline $\mathrm{IgG}_{4}$ & $3-6$ & 6 \\
\hline Anticomplementary activity (\%) & $\leq 50$ & 39 \\
\hline Thermo stability $\left(57^{\circ} \mathrm{C} / 4 \mathrm{~h}\right)$ & No gelification & No gelification \\
\hline Antibody to hepatitis B surface antigen ${ }^{(d)}$ & Minimum $0.5 \mathrm{IU} / \mathrm{g}$ & $1.24 \mathrm{IU} / \mathrm{g}$ \\
\hline Pyrogen ${ }^{(\mathrm{e})}$ & Absence & Absence \\
\hline
\end{tabular}

${ }^{(a)}$ Analyzed by fluorescamine standard curve. ${ }^{(b)}$ Determined by Kjeldahl method. ${ }^{(\mathrm{C})}$ Determined by electrophoresis. ${ }^{(\mathrm{d})}$ By using ELISA kit assays against hepatitis. ${ }^{(e)}$ Determined by using detection kit and analyzed by PCR.

anti-dengue antibody titers of 1:1280 for DENV-2 and 1:160 for DENV-1 and DENV-3. This was expected, since this IVIG was prepared using blood donations from Brazil, which is an endemic area (Cordeiro et al., 2007). In Brazil, three serotypes are currently in circulation, DENV-1, 2, and 3, while infection by DENV-4 is more restricted to the North Region (Roraima, Manaus and Belém) (Brazil, 2010, 2011a, 2011b). The broad neutralizing property in relation to the different virus types confirmed the functional activity of this IgG product. The commercial IVIG (prepared from American blood donations, brand Kiovig/ Baxter) was found to have low titers for DENV.

TABLE II - Dengue antibody titers of the specific immunoglobulin preparation by plaque reduction

\begin{tabular}{lccc}
\hline \multirow{2}{*}{ Sample* } & \multicolumn{3}{c}{ antibodies } \\
\cline { 2 - 4 } & DENV-1 & DENV-2 & DENV-3 \\
\hline Crude plasma & $1: 160$ & $1: 640$ & $1: 40$ \\
Anti-dengue IgG & $1: 160$ & $1: 1280$ & $1: 160$ \\
Trademark (Kiovig) & $1: 40$ & $1: 40$ & $<1: 20$ (negative) \\
\hline
\end{tabular}

*Experiments were repeated at least three times independently. The data here present the mean for one single experiment.

Several preparations of IVIG are now available for therapy, however it is well known that different plasma sources may influence the immunological composition of IVIG. In clinical practice, different preparations of IVIG or different batches may result in variable beneficial effects. For a biological study, it is therefore very important to describe the reasons for choosing a preparation of IVIG and to consider the specific characteristics of the product that are relevant to a particular clinical response (Elluru et al., 2006; Gelfand, 2006; Gürcan, Keskin, Ahmed, 2010).

The knowledge of virology gathered over the years suggests that specific IVIGs are useful for virus neutralization. This is the case for hepatitis B and for the arbovirus West Nile virus (WNV). If we compare dengue and WNV, both infections are immunologically and pathogenically similar to each other and have a similar infection course. It has also been reported that specific anti-WNV IgGs are efficient in reducing virus titers in patients severely-infected with WNV (Saquib et al., 2008; Wadei et al., 2004; Haley et al., 2003). In pre-clinical studies, anti-WNV IgGs substantially reduced mortality in WNV-infected mice. In contrast, the mortality is observed in WNV-infected mice when a polyvalent is administered instead of specific IgG (Ben-Nathan et al., 2003). In light of these findings, investigation of the potential of specific human anti-dengue IgG would appear to be a reasonable proposition.

The feasibility of a Brazilian IVIG, with anti-dengue antibody titers for treatment of dengue-patients, would 
involve the same approach currently employed for patients with WNV (Saquib et al., 2008; Wadei et al., 2004; Haley et al., 2003). However, the safety of using this type of preparation in dengue-patients should be confirmed. The pre-existence of heterologous antibodies, in the presence of a new infection by a distinct serotype may cause ADE (Gubler, 2002; Guzmán, Kouri, 2004; Ross, 2010; Wilder-Smith et al., 2005). Since all four serotypes exist in Brazil, further studies are necessary to confirm whether a treatment based on Brazilian IVIG is safe for denguepatients or may cause ADE.

\section{CONCLUSION}

The present study has described, for the first time, the production and biophysical/biochemical validation of a human anti-dengue IVIG prepared using Brazilian blood donations. The product was characterized in regarding to its immunoglobulin composition, biophysical parameters, purity and capacity to neutralizing Dengue antibodies. As expected, this anti-Dengue IgG preparation exhibited higher titers of anti-dengue antibodies than a trademark product, which is produced by plasma of donors living in nonendemic Dengue areas. The anti-dengue IVIG described here is useful for investigating the effect of anti-dengue IVIG during infection and its potential therapeutic use.

\section{ACKNOWLEDGEMENTS}

This study received funding from FACEPE (PPSUS Program, grant number APQ-1380-4.00/08) and the Instituto Nacional de Pesquisas em Dengue (INCT em Dengue, CNPq, grant number 573876/2008-8). The authors are deeply grateful to all the HEMOPE employees for their help during the study. F.L.G. is receiving a FACEPE scholarship for doctoral studies, while R.M.B.O. is receiving a scholarship from INCT em Dengue. A.C.L.L. receives a senior scholarship awarded by $\mathrm{CNPq}$ (research productivity grant program).

\section{LIST OF ABBREVIATIONS}

ADE - Antibody-Dependent Enhancement, DENV - Dengue Virus, DF - Dengue Fever, DHF - Dengue Hemorrhagic Fever, DSS - Dengue Shock Syndrome, ELISA - Enzyme-Linked Immunosorbent Assay, FCS Fetal Calf Serum, HBsAg - Hepatitis B Surface Antigens, HCV - Hepatitis C Virus, HEMOPE - Hematology and Hemotherapy Foundation of Pernambuco, HIV - Human Immunodeficiency Virus, HTLV - Human T Lymphotropic Virus, IVIG - Intravenous Immunoglobulins G, LACEN-
PE - Central Laboratory of Pernambuco, MEM Minimum Essential Medium, PRNT - Plaque-Reduction Neutralization Test, Rho - Anti-D IgG, S/D - Solvent/ Detergent, TNBP - Tri- $n$-Butyl Phosphate, WNV - West Nile virus.

\section{REFERENCES}

ACHIRON, A.; GABBAY, U.; GILAD, R.; HASSINBAER, S.; BARAK, Y.; GORNISH, M.; ELIZUR, A.; GOLDHAMMER, Y.; SAROVA-PINHAS, I. Intravenous immunoglobulin treatment in multiple sclerosis: effect on relapses. Neurology, v.50, p.398-402, 1998.

ACHIRON, A.; MOR, F.; MARGALIT, R.; COHEN, I.R.; LIDER, O.; MIRON, S. Suppression of experimental autoimmune encephalomyelitis by intravenously administered polyclonal immunoglobulins. J. Autoimmun., v. 15, p.323-330, 2000.

ATKINS, J.T.; KARIMI, F.; MORRIS, E.H.; DAVID, G.; SHIM, S. Prophylaxis for respiratory syncytial virus with respiratory syncytial virus-immunoglobulin intravenous among preterm infants of thirty-two weeks gestation and less: reduction in incidence, severity of illness and cost. Pediatr. Infect. Dis. J., v.19, p.138-143, 2000.

BEN-NATHAN, D.; LUSTIG, S.; TAM, G.; ROBINZON, S.; SEGAL, S.; RAGER-ZISMAN, B. Prophylactic and therapeutic efficacy of human intravenous immunoglobulin in treating West Nile Virus infection in mice. J. Infect. Dis., v.188, p.5-12, 2003.

BIESERT, L. Virus validation studies of immunoglobulin preparations. Clin. Exp. Rheumatol., v.14, p.S47-S52, 1996.

BOS, O.J.; SUNYE, D.G.; NIEUWEBOER, C.E.; VAN, E.F.A.; SCHUITEMAKER, H.; OVER, J. Virus validation of $\mathrm{pH}$ 4-treated human immunoglobulin products produced by the Cohn fractionation process. Biologicals, v.26, p.267276, 1998.

BRASIL. Secretaria de Vigilância em Saúde. Nota técnica: isolamento do vírus DENV 4 em Roraima, Brasil. Brasília, 2010. Available at: <http:// portal.saude.gov.br/portal/saude/ profissional/area $>$. Accessed on: 08 Dec. 2010.

BRASIL. Secretaria de Vigilância em Saúde. Nota técnica: isolamento do sorotipo DENV 4 em Manaus/AM. Brasília, 2011a. Available at: <http://portal.saude.gov.br/portal/ saude/profissional/area $>$. Accessed on: 18 Jan. 2011. 
BRASIL. Secretaria de Vigilância em Saúde. Nota técnica: isolamento do sorotipo DENV 4 em Belém/PA. Brasília, 2011b. Available at: <http://portal.saude.gov.br/portal/ saude/profissional/area>. Accessed on: 25 Feb. 2011.

BRENNAN, D.C. Polyclonal antibodies in immunosuppression. Transplant. Proc., v.33, p.1002-1004, 2001.

BJORKANDER, J.; HAMMARSTROM, L.; SMITH, C.I.; BUCKLEY, R.H.; CUNNINGHAM-RUNDLES, C.; HANSON, L.A. Immunoglobulin prophylaxis in patients with antibody deficiency syndromes and anti-IgA antibodies. J. Clin. Immunol., v.7, p.8-15, 1987.

CHANG, C.E.; EO, H.G.; LEE, Y.S.; CHUNG, S.K.; SHIN, J.S.; LAH, Y.K.; PARK, C.W.; JUNG, J.T.; HUH, J.W.; LEE, S.M. Human intravenous immunoglobulin preparation and virus inactivation by pasteurization and solvent detergent treatment. Prep. Biochem. Biotechnol., v.30, p.177-197, 2000 .

CHUANG, V.W.; WONG, T.Y.; LEUNG, Y.H.; MA, E.S.; LAW, Y.L.; TSANG, O.T.; CHAN, K.M.; TSANG, I.H.; QUE, T.L.; YUNG, R.W.; LIU, S.H. Review of dengue fever cases in Hong Kong during 1998 to 2005. Hong Kong Med. J., v.14, p.170-177, 2008.

COHN, E.J.; STRONG, L.E.; HUGHES, W.L.J.R.; MULFORD, D.J.; ASHWORTH, J.N.; MELIN, M.; TAYLOR, H.L. Preparation and properties of serum and plasma proteins III. A system for the separation into fractions of the protein and lipoprotein components of biological tissues and fluids. J. Am. Chem. Soc., v.68, p.459-475, 1946.

CORDEIRO, T.M.; SILVA, M.A.; BRITO, A.A.C.; NASCIMENTO, M.J.E.; MAGALHÃES, F.C.M.; GUIMARÃES, F.G.; SILVA, L.N.; CARVALHO, F.M.E.; MARQUES, A.T.E. Characterization of a dengue patient cohort in Recife, Brazil. Am. J. Trop. Med. Hyg., v.77, p.1128-1134, 2007.

CUMMINGS, D.A.T.; IAMSIRITHAWORN, S.; LESSLER, J.T.; MCDERMOTT, A.; PRASANTHONG, R.; NISALAK, A.; JARMAN, R.G.; BURKE, D.S.; GIBBONS, R.V. The impact of the demographic transition on dengue in thailand: insights from a statistical analysis and mathematical modeling. PLoS. Med., v.6, p.e1000139, 2009.
DALAKAS, M.C.; ILLN, I.; DAMBROSIA, J.M.; SOUEIDAN, S.A.; STEIN, D.P.; OTERO, C. A controlled trial of highdose intravenous immune globulin infusions as treatment for dermatomyositis. N. Engl. J. Med., v.27, p.1993-2000, 1993.

ELLURU, S.; HUYEN, J.D.V.; BAYRY, J.; DELIGNAT, S.; PROST, F.; EPHREM, A.; SIBERIL, S.; MISRA, N.; DESMZES, S.L.; KAZATCHKINE, M.D.; KAVERI, S.V. Comparative study of the anti-inflammatory effect of two intravenous immunoglobulin preparations manufactured by different processes. Immunol. Lett., v.107, p.58-62, 2006.

FIGUEIREDO L. Dengue in Brazil during 1999-2009: a review. Dengue bullettin. WHO Regional Office for South-East Asia, 2010. v.34, p.6-12.

GELFAND, M.D.J. Antibody-directed therapy: past, present, and future. J. Allergy Clin. Immunol., v.108, p.S111-S116, 2001.

GELFAND, E.W. Differences between IGIV products: impact on clinical outcome. Int. Immunopharmacol., v.6, p.592$599,2006$.

GUBLER, D.J. Dengue and dengue hemorrhagic fever. Clin. Microbiol. Rev., v.11, p.480-496, 1998.

GUBLER, D.J. Epidemic dengue/ dengue hemorrhagic fever as a public health, social and economic problem in the $21 \mathrm{st}$ century. Trends Microbiol., v.10, p.100-103, 2002.

GÜRCAN, H.M.; KESKIN, D.B.; AHMED, A.R. Information for healthcare providers on general features of IGIV with emphasis on differences between commercially available products. Autoimmun. Rev., v.9, p.553-559, 2010.

GUZMÁN, M.G.; KOURI, G. Dengue: an update. Lancet Infect. Dis., v.2, p.33-42, 2002.

GUZMÁN, M.G.; KOURI, G. Dengue diagnosis, advances and challenges. Int. J. Infect. Dis., v.8, p.69-80, 2004.

HALEY, M.; RETTER, A.S.; FOWLER, D.; GEABANACLOCHE, J.; O'GRADY, N.P. The role for intravenous immunoglobulin in the treatment of West Nile virus encephalitis. Clin. Infect. Dis., v.37, p.88-90, 2003. 
HANN, A.F.; BOLTON, C.F.; ZOCHODNE, D.; FEASBY, T.E. Intravenous immunoglobulin treatment in chronic inflammatory demyelinating polyneuropathy. Adouble-blind, placebo-controlled study. Brain, v.119, p.1067-1077, 1996.

HALSTEAD, S.B. In vivo enhancement of dengue virus infection in rhesus monkeys by passively transferred antibody. J. Infect. Dis., v.140, p.527-533, 1979.

HALSTEAD, S.B. Neutralization and antibody-dependent enhancement of dengue viruses. Adv. Virus Res., v.60, p.421-467, 2003.

HOROWITZ, B.; WIEBE, M.E.; LIPPIN, A.; STRYKER, M.H. Inactivation of viruses in labile blood derivatives. Disruption of lipid-enveloped viruses by tri (n-butyl) phosphate detergent combinations. Transfusion, v.25, p.516-522, 1985.

KROEZ, M.; KANZY, E.J.; GRONSKI, P.; DICKNEITE, G. Hypotension with intravenous immunoglobulin therapy: importance of $\mathrm{pH}$ and dimer formation. Biologicals, v.31, p.277-286, 2003.

LINNEN, J.M.; VINELLI, E.; SABINO, E.C.; TOBLER, L.H.; HYLAND, C.; LEE, T.H.; KOLK, D.P.; BROULIK, A.S.; COLLINS, C.S.; LANCIOTTI, R.S.; BUSCH, M.P. Dengue viremia in blood donors from Honduras, Brazil, and Australia. Transfusion, v.48, p.1355-1362, 2008.

LORIES, R.J.; MAERTENS, J.A.; CEUPPENS, J.L.; PEETERMANS, W.E. The use of polyclonal intravenous immunoglobulins in the prevention and treatment of infectious diseases. Acta Clin. Belg., v.55, p.163-169, 2000.

LUCENA, A.E.S.; SAMPAIO D.S.; SILVA, E.R.; DE PAIVA, V.F.; SANTIAGO, A.C.; LEITE, A.C.L. A new methodology for polyvalent intravenous immunoglobulin solution production with a two-stage process of viral inactivation. Braz. J. Pharm. Sci., v.46, p.776-783, 2010.

MOHAMMED, H.; LINNEN, J.M.; MUÑOZ-JORDÁN, J.L.; TOMASHEK, K.; FOSTER, G.; BROULIK, A.S.; PETERSEN, L.; STRAMER, S.L. Dengue vírus in blood donations, Puerto Rico, 2005. Transfusion, v.48, p.1348$1354,2008$.

MORELL, A.; SKVARIL, F.; STEINBERG, A.G.; VAN LOGHEM, E.; TERRY, W.D. Correlations between the concentrations of the four sub-classes of IgG and $\mathrm{Gm}$ Allotypes in normal human sera. J. Immunol., v.108, p.195206, 1972.
MORENS, D.M.; HALSTEAD, S.B.; REPIK, P.M.; PUTVATANA, R.; RAYBOURNE, N. Simplified plaque reduction neutralization assay for dengue viruses by semimicro methods in BHK-21 cells: comparison of the BHK suspension test with standard plaque reduction neutralization. J. Clin. Microbiol., v.22, p.250-254, 1985.

NISHIURA, H.; HALSTEAD, S.B. Natural history of dengue vírus (DENV)-1 and DENV-4 infections: reanalysis of classic studies. J. Infect. Dis., v.195, p.1007-1013, 2007.

NOGUEIRA，R.M.R.; SCHATZMAYR，H.G.; MIAGOSTOVICH, M.P.; FARIAS, M.F.; FARIAS FILHO, F.C. Virological study of a dengue type 1 epidemic at Rio de Janeiro. Mem. Inst. Oswaldo Cruz, v.83, p.219-225, 1988.

OHLSSON, A.; LACY, J. B. Intravenous immunoglobulin for preventing infection in preterm and/or low-birth-weight infants. Cochrane Database Syst. Rev., n.2, 2001, Art. No.CD000361.

OKWUNDU, C.I.; AFOLABI, B.B. Intramuscular versus intravenous anti-D for preventing rhesus alloimmunization during pregnancy. Cochrane Database Syst. Rev., n.1, 2013, Art. No. CD007885.

OMAR, A.; KEMPF, C.; IMMELMANN, A.; RENTSCH, M.; MORGENTHALER, J.J. Virus inactivation by pepsin treatment at $\mathrm{pH} 4$ of IgG solutions: factors affecting the rate of virus inactivation. Transfusion, v.36, p.866-872, 1996.

ONCLEY, J.L.; MELIN, M.; RICHERT, D.A.; CAMERON, J.W.; GROSS, P.M. The separation of the antibodies, isoaglutinins, prothrombin, plasminogen and betalipoprotein into subfractions of human plasma. J. Am. Chem. Soc., v.71, p.541-550, 1949.

OOI, E.E.; GOH, K.T.; GUBLER, D.J. Dengue prevention and 35 years of vector control in Singapore. Emerg. Infect. Dis., v.12, p.887-893, 2006.

ORANGE, J.S.; HOSSNY, E.M.; WEILER, C.R.; BALLOW, M.; BERGER, M.; BONILLA, F.A.; BUCKLEY, R.; CHINEN, J.; EL-GAMAL, Y.; MAZER, B.D.; NELSON, R.P.; PATEL, D.D.; SECORD, E.; SORENSEN, R.U.; WASSERMAN, R.L.; CUNNINGHAM-RUNDLES, C. Use of intravenous immunoglobulin in human disease: a review of evidence by members of the primary immunodeficiency committee of the American Academy of Allergy, Asthma and Immunology. J. Allergy Clin. Immunol., v.117, p.525$553,2006$. 
OSANAI, C.H.; TRAVASSOS DA ROSA, A.P.A.; TANG, A.T.; AMARAL, R.S.; PASSOS, A.D.C.; TAUIL, P.L. Surto de dengue em Boa Vista Roraima. Rev. Inst. Med. Trop., v.25, p.53-54, 1983.

REID, K.G.; CUTHBERTSON, B.; JONES, A.D.; MCINTOSH, R.V. Potential contribution of mild pepsin treatment at $\mathrm{pH} 4$ to the viral safety of human immunoglobulin products. Vox Sang., v.55, p.75-80, 1988.

ROSS, T.M. Dengue virus. Clin. Lab. Med., v.30, p.149-160, 2010.

SAQUIB, R.; RANDALL, H.; CHANDRAKANTAN, A.; SPAK, C.W.; BARRI, Y.M. West Nile virus encephalitis in a renal transplant recipient: the role of intravenous immunoglobulin. Am. J. Kidney Dis., v.52, p.19-21, 2008.

SOUZA, D.G.; FAGUNDES, C.T.; SOUSA, L.P.; AMARAL, F.A.; SOUZA, R.S.; SOUZA, A.L.; KROON, E.G.; SACHS, D.; CUNHA, F.Q.; BUKIN, E.; ATRASHEUSKAYA, A.; IGNATYEV, G.; TEIXEIRA, M.M. Essential role of platelet-activating factor receptor in the pathogenesis of Dengue virus infection. Proc. Natl. Acad. Sci. U.S.A., v.106, p.14138-14143, 2009.

TAMBYAH, P.A.; KOAY, E.S.; POON, M.L.; LIN, R.V.; ONG, B.K. Dengue hemorrhagic fever transmitted by blood transfusion. N. Engl. J. Med., v.359, p.1526-1527, 2008.

UEMURA, Y.; YANG, Y.H.; HELDEBRANT, C.M.; TAKECHI, $\mathrm{K}$.; YOKOYAMA, K. Inactivation and elimination of viruses during preparation of human intravenous immunoglobulin. Vox Sang., v.67, p.246-254, 1994.
VAUGHN, D.W.; GREEN, S.; KALAYANAROOJ, S.; INNIS, B.L.; NIMMANNITYA, S.; SUNTAYAKORN, S.; ENDY, T.P.; RAENGSAKULRACH, B.; ROTHMAN, A.L.; ENNIS, F.A.;. NISALAK, A. Dengue viremia titer, antibody response pattern, and virus serotype correlate with disease severity. J. Infect. Dis., v.181, p.2-9, 2000.

VYAS, G.N.; PERKINS, H.A.; FUDENBERG, H.H. Anaphylactoid transfusion reactions associated with antiIgA. Lancet, v.2, p.312-315, 1968.

WADEI, H.; ALANGADEN, G.J.; SILLIX, D.H.; EL-AMM, J.M.; GRUBER, A.S.; WEST, M.S.; GRANGER, D.K.; GARNICK, J.; CHANDRASEKAR, P.; MIGDAL, S.D.; HARIRIAN, A. West Nile virus encephalitis: an emerging disease in renal transplant recipients. Clin. Transplant., v.18, p.753-758, 2004.

WERDAN, K. Intravenous immunoglobulin for prophylaxis and therapy of sepsis. Curr. Opin. Crit. Care, v.7, p.354$361,2001$.

WILDER-SMITH, A.; YOKSAN, S.; EARNEST, A.; SUBRAMANIAM, R.; PATON, N.I. Serological evidence for the co-circulation of multiple dengue virus serotypes in Singapore. Epidemiol. Infect., v.133, p.667-671, 2005.

WILDER-SMITH, A.; SCHWARTZ, E. Dengue in travelers. $N$. Engl. J. Med., v.353, p.924-932, 2005.

WILDER-SMITH, A.; OOI, E.; VASUDEVAN, S.G.; GUBLER, D.J. Update on dengue: epidemiology, virus evolution, antiviral drugs, and vaccine development. Curr. Infect. Dis. Rep., v.12, p.157-164, 2010.

Received for publication on $25^{\text {th }}$ January 2013 Accepted for publication on $13^{\text {th }}$ May 2013 